\section{SOI: $1.1 / \mathrm{TAS} \quad$ DOI: $10.15863 / \mathrm{TAS}$ International Scientific Journal Theoretical \& Applied Science}

p-ISSN: $2308-4944$ (print)

e-ISSN: 2409-0085 (online)

Year: 2017

Issue: 06

Volume: 50

Published: $24.06 .2017 \quad$ http://T-Science.org
Avaz Jamolovich Kakhkharov

$\mathrm{PhD}$ student of marketing department,

Tashkent State University of economics, avaz_qaxxorov@mail.ru phone: + 99890-966-50-31

SECTION 31. Economic research, finance, innovation, risk management.

\title{
SYSTEMATIZATION OF CRITERIA CLARIFYING EFFECTIVENESS OF INNOVATIVE MARKETING PRACTICES IN THE SYSTEM OF ROAD TRANSPORT
}

Abstract: This article is dedicated to apply methodological approach related to the criteria clarifying effectiveness of innovative marketing practices in the system of road transport. The main reason of investigating the measures which associated with effectiveness of innovative marketing practices in road transport system is to select effectiveness indicators and apply them into practice. Research results enable criteria related to effectiveness of innovative marketing practices in the system of road transport and its evaluation steps to be applied into practice, provide an opportunity to use methodologies of finding effectiveness of innovative marketing practices as well as helps to make decisions in innovative development.

Key words: innovation, criteria, effectiveness, innovative marketing, effectiveness of innovative marketing, effectiveness of innovative marketing in the system of road transport.

Language: English

Citation: Kakhkharov AJ (2017) SYSTEMATIZATION OF CRITERIA CLARIFYING EFFECTIVENESS OF INNOVATIVE MARKETING PRACTICES IN THE SYSTEM OF ROAD TRANSPORT. ISJ Theoretical \& Applied Science, 06 (50): 70-73.

Soi: http://s-o-i.org/1.1/TAS-06-50-6

Doi: crossef https://dx.doi.org/10.15863/TAS.2017.06.50.6

\section{INTRODUCTION}

It is true that in this contemporary conditions of marketing reformations methodological basics play crucial role in implementing deep modifications, consolidating financial situation of manufacturing and service organizations and evaluating effectiveness of product quality and volume as well as the policy of innovation and investment. Nowadays we can see an inadequacy of methodological base in establishment and monitoring, as well as evaluation and assessment of marketing activities of automobile industry system. Especially we can consider that in the market of automobile industry service it is impossible to achieve potential outcomes in efficient development of marketing activities without applying certain methods for evaluating its effectiveness.

\section{IMPORTANCE OF THE TOPIC}

Apparently,today there are several disproportions between theory and practice. For example even though there is a need to create methodological bases of assessing the effectiveness of innovative marketing, there has been a lack of initiative to create and indicator it. For this reason, in establishing prospective long term strategic plans, first of all, it is essential to create methodological bases of assessing the effectiveness of innovative marketing or commercialization of industry services.

Thus, in any kind of organization methodological bases of assessing the effectiveness of innovative marketing requires generating aspects of its definition and the urgency of systematization of its results.

The main reason of investigating detailed criteria of effectiveness of innovative marketing activities in industry of automobiles consists of choosing indicators underlying and measuring effectiveness and applying them in evaluation process.

Relying on the objective of this research special criteria is chosen in assessing the effectiveness of innovative marketing. These criteria play important role in shaping the provision of contemporary methodological basics in evaluating effectiveness of innovative marketing in the system of automobile industries.

\section{LITERATURE REVIEW}


Nowadays research works of foreign scientists related to showing criteria regarding the effectiveness of innovations as well as innovative marketing practices and creating assessment methods, are of high importance.

Generally speaking, special researches of Michael Porter play important role in the areas associated with choosing any kind of activity in business, from the source of raw materials to analyzing and valuation of a chain of activities such as creating innovative product, its pricing and delivering it to final customer [1].

According to T. Ambler marketing effectiveness of an organization encompasses three components. First one is to evaluate effectiveness of marketing in increasing the diversity of products for developing the entity and increasing the profit holding the market share upwards.

Second component consists of the process of evaluating effectiveness in the case of functional marketing. In this case the purpose is to acquire different marketing-mix results by applying various innovative technologies in moving any kind of product. Third one deals with evaluation of different expenses allocated for marketing practices such as the measurements related to marketing budget. For the expenditures incurred for production of innovative product or service the "marketing budget" office which is contained in management and financial expenses department of the organization takes the responsibility [2].

In modern scientific literatures there is different perspective to be applied in evaluating effectiveness of innovative practices [3]:

- the position of evaluating investment effectiveness of innovative practices

- evaluation position of investment efficiencies according to acquiring results

-Evaluation process of implementation of innovative practices in each phase and different directions and others.

According to the researches of A. Barisheva effectiveness of innovative practices are evaluated according to their economical and scientific criteria [4]. In addition, C. Dedkov [5] indicates that effectiveness of innovative practices are assessed by the results of scientific and social effectiveness. Medinskiy [6] believe that it would be correct to relate effectiveness of innovative practice with effectiveness all phases utilized in innovative activities.

German scientists I.V.Babin and Y.A.Mellers notified that in evaluating effectiveness of innovative practices ,first of all, criteria in commercialization and producing innovative products should be systemized and measurements related to successful commercialization movement should be evaluated. In this case methodological bases of assessing the effectiveness of innovative marketing is mentioned and other effectiveness measurement criteria ranging from economic, financial, social resources to ecologic and collaborative scientific-technological are investigated [3].

There are several scientists who have done a range of researches in evaluating effectiveness of commercialization and creating innovative products. For example, A.A. Stepano, I.Yu.Evgrafova, Ya. Sobon, M. Rogozinsk and other scientists have taken investigation of innovative marketing effectiveness into consideration in their research works.

Some of the scientist in Uzbekistan in the sphere of economics such as SH.N. Zaynutdinov and N.M. Rasulov have prepared scientificmethodological guidance related to evaluating innovative effectiveness of the practices in the entities which make big difference among students learning this sphere.

Some of the specialists in road construction industry Ravshanov who used evaluation methods in assessing capabilities of road and transportation complexes and T.U. Qodirov who used this system in assessing effectiveness of competitiveness of road transport system has managed to evaluate effectiveness criteria in using social and economic resources.

For this reason, due to absence of research papers associated with methodological bases of assessing the effectiveness of innovative marketing in road transport industry among the works of scientists whose works have been analyzed we decided to systemize evaluation criteria.

\section{MAIN PART OF THE RESEARCH}

In order to investigate the criteria clarifying effectiveness of innovative marketing practices in the market of road transport services, first of all, those criteria are selected according to their features and then their results are systemized.

Table 1

The system of the indicators and criteria which clarify effectiveness of innovative marketing practices in road transports.

\begin{tabular}{|l|l|l|}
\hline № & Criteria & \multicolumn{1}{c|}{ Content of criteria } \\
\hline $\mathbf{1}$ & Economic & $\begin{array}{l}\text { This criteria provides the capacity associated with the provision of transportation and } \\
\text { logistics services as well as economic productivity of road transport organizations by } \\
\text { using existing fund and turnover finance appropriately. }\end{array}$ \\
\hline $\mathbf{2}$ & Social & Social factors clarify the provision of qualitative and reasonable transportation services \\
\hline
\end{tabular}




\section{Impact Factor:}

\begin{tabular}{ll|lr} 
ISRA $($ India) $=\mathbf{1 . 3 4 4}$ & SIS (USA) & $=\mathbf{0 . 9 1 2}$ \\
ISI $($ Dubai, UAE) $=\mathbf{0 . 8 2 9}$ & PИНЩ (Russia) $=\mathbf{0 . 2 3 4}$ \\
GIF (Australia) $=\mathbf{0 . 5 6 4}$ & ESJI $($ KZ) & $=\mathbf{3 . 8 6 0}$ \\
JIF & $=\mathbf{1 . 5 0 0}$ & SJIF $($ Morocco $)=\mathbf{2 . 0 3 1}$
\end{tabular}

\begin{tabular}{|c|l|l|}
\hline $\mathbf{3}$ & Financial & $\begin{array}{l}\text { to community, convenience of transportation modes as well as the importance of level } \\
\text { of such kind of amenities to society. }\end{array}$ \\
\hline $\mathbf{4}$ & $\begin{array}{l}\text { Marketing criterion defines the capabilities of road transport organizations in terms of } \\
\text { financing their operations and clarifies financial sustainability of the organization, } \\
\text { whether the entity possesses financial resources which are essential for its operations } \\
\text { and is able to pay its debts. }\end{array}$ \\
\hline $\mathbf{5}$ & $\begin{array}{l}\text { Technical- } \\
\text { operational }\end{array}$ & $\begin{array}{l}\text { It defines the effectiveness of managements decisions in marketing as well as } \\
\text { transportation service practices related to satisfying the demand of society to } \\
\text { transportation services by innovative ways. }\end{array}$ \\
\hline $\mathbf{6}$ & Ecologic & $\begin{array}{l}\text { This criteria, which illustrates technical, technological and economic features of road } \\
\text { transport organizations, clarifies the ways of choosing appropriate transportation } \\
\text { modes and utilizing them efficiently. }\end{array}$ \\
\hline $\mathbf{7}$ & Ergonomic & $\begin{array}{l}\text { It explains ecologic cleanliness and negative effect of transporting to people and } \\
\text { environment during the process of providing transportation services. }\end{array}$ \\
\hline $\mathbf{8}$ & Safety & $\begin{array}{l}\text { It provides ecologic, conveying, mobility safeties of transportation modes and } \\
\text { commuters when performing transportation services. }\end{array}$ \\
\hline
\end{tabular}

The following are the measurement groups of the criteria that clarify the effectiveness of innovative marketing practices in road transport:

1. Economic indicators defining the effectiveness of innovative marketing practices: the capacity of carrying commuters and load; turnover of load and commuters; the park of transportation modes and their infrastructures; conveying area and its utilization level; provision of technical service and repairing to transportation modes and their quality measures; revenue and profit of an entity; rate of revenue; overall and conveying profitability cost of transporting and others

2. Social indicators defining the effectiveness of innovative marketing practices: satisfaction level of customers in transportation service system; availability of transportation modes in the area; opportunities of using transportation services; comfort ability of transportation modes and the importance of its functions to society.

3. Financial indicators defining the effectiveness of innovative marketing practices: financial capacity; liquidity ratio; ratio of effectiveness; financial sustainability ratio; profitability ratio; indicators of its attractiveness to provide investment.

4. Marketing and management indicators defining the effectiveness of innovative marketing practices: share in the market of transportation services; brand of transportation organization and its popularity; tariff policy and its flexibility; technology, technical tools and organizational mobility of service; advertising practices; news related to market of transportation services, its acquisition and recycling quality; tariff of transporting; discounts; capabilities of management and engineering staff; structure of management; quality communication technologies used in management; strategic level of implementing management decisions.

5. Technical-operational indicators defining the effectiveness of innovative marketing practices: number of automobiles in the list of vehicles in automobile transport organizations; overall carrying capability of automobile transport organizations (overall passenger capacity); average daily distance of an automobile; annual distance of automobiles; overall distance of automobile with load; overall number of movements; ratio of technical readiness of automobiles; operational ratio of automobiles; average operational speed; capacities of loading; economization; reliability, utilization of weight and size.

6. Ecologic indicators defining the effectiveness of innovative marketing practices: ecologic cleanliness of carrying during transportation services; negative effect to environment and human health; ecological level of fuel; ecological impact of road and infrastructure facilities.

7. Operational indicators defining the effectiveness of innovative marketing practices: health requirements; anthropometric requirements; physiological requirements; psychological requirements; cultural-ethical requirements and others.

8. Safety indicators defining the effectiveness of innovative marketing practices: safety of passengers while providing transportation services; safety of the movement of transportation modes; labor safety; ecological safety; carrying safety; safety of drivers and technic staff. Our research results related to the effectiveness of innovative marketing practices in road transport system show that organizations should rely on a methodology based on the features of chosen criteria. 


\section{RESULTS OF THE RESEARCH}

The methodology of evaluating effectiveness enables to make appropriate decisions in innovative development of road transport organization's practices, complex investigation of transportation service markets and determining innovative practice areas, issuing measures related to increasing marketing and innovative capabilities in transportation organizations and future prosperities of transportation service systems in the country.

All above mentioned processes will be united and it will be used in systemizing criteria in evaluating effectiveness of innovative marketing practices in road transport system and selecting indicators. After that appropriate method of evaluation will be created evaluations will be implemented. After that results will be analyzed for making correct decision.

In global practices innovative marketing practices are directed to forming the strategy of corporate competition and its effectiveness is evaluated for satisfying customers completely, gaining new markets and increasing sales volumes. During penetration into new markets, forming competition and pricing strategies show effectiveness of innovative marketing practices in life expectancy and brand of products.
Forming criteria which show effectiveness of innovative marketing practices in road transport system and applying its evaluation steps into practice enables entities to use methods of determining effectiveness of innovative marketing practices which eventually plays important role in making innovative development decisions of an organization.

\section{CONCLUSION}

From our point of view, these criteria explore the most important measures of evaluating innovative activities, lead all indicators to united assessment system, applying innovative transportation services into practice in the market of transportation system or allow to find of objective evaluations measurements in certain transportation system. In addition, relying on these criteria an opportunity to supervise services being provided by transportation modes immediately and compare results of an entity in different periods during the process of evaluation of innovative marketing effectiveness can be attained. Relying on this information it can be concluded that it is very crucial to select criteria of evaluating effectiveness of innovative marketing practices in road transport organizations.

\section{References:}

1. Porter ME (2006) Competitive strategy. Methodology of analysis of industries and competitors; Per. With Eng., $2^{\text {nd }}$ ed. Moscow: Alpina Business Books, 452.

2. Ambler $T$ (1999) Practical marketing. St. Petersburg: Peter.

3. Babyna IV, Meller YA (2017) Methodical approach to integrated assessment of the organization's innovation activities. Available: http://www.bsu.by/Cache/pdf/126143.pdf

(Accessed: 10.06.2017).

4. Barysheva AV (2007) Innovative management: a tutorial / ed. A.V. Barysheva. - Moscow, $384 p$.

5. Dedkov S (2007) Monitoring of scientific and innovative activities: some issues of methodology // Science and innovation. - 2007. № 3.-With. 60 - 62.
6. Medynsky VG (2008) Innovative management: a textbook / V. Medynsky. - Moscow: INFRA M., - 295p.

7. Stepanov AA (2014) Essence, regularities and principles of management of the effectiveness of social and economic development of the region // Bulletin of the Moscow City Pedagogical University. Series "Economics". No. 1 (25), - p. 66-72.

8. Ravshanov MN (2012) Economic capabilities of road and transportation system: problems and solutions. T: NA, p. 209.

9. Kadyrov TU (2014) "The competitiveness of road transport: organizational and economic mechanisms" for the degree of Doctor of Economic Sciences. -T .: Tashkent Automotive Road Institute, - $142 \mathrm{p}$.

10. Zaynutdinov SN (2011) Innovative capacitybuilding strategy. // Economy and innovative technology, scientific e-journal №1. 